\title{
CONCEPT OF TRIANGLE: EXAMPLES OF MATHEMATICAL ABSTRACTION IN TWO DIFFERENT CONTEXTS
}

\author{
1Farida Nurhasanah, ${ }^{2}$ Yaya S. Kusumah, ${ }^{3}$ Jozua Sabandar \\ 1 Universitas Sebelas Maret, Jl. Ir. Sutami. No. 36A Jebres, Surakarta 57126 \\ 2Universitas Pendidikan Indonesia, Jl. Dr. Setiabudhi, No. 229, Bandung 40154 \\ ${ }^{3}$ STKIP Siliwangi, Jl. Terusan Jend. Sudirman No. 3 Baros, Cimahi Tengah 40526 \\ e-mail: nurhasanahfarida@gmail.com
}

\begin{abstract}
Abstrak
Konsep geometri yang abstrak tidak dapat ditransfer begitu saja dalam bentuk informasi, melainkan harus dikonstruksi dalam benak mereka sendiri. Proses konstruksi konsep yang terjadi dalam benak siswa dengan memanfaatkan pengetahuan awal mereka, disebut sebagai proses abstraksi matematis. Penelitian ini bertujuan untuk mengekplorasi proses abstraksi siswa dalam belajar konsep segitiga pada dua konteks yang berbeda. Penelitian ini merupakan penelitian kualitatif menggunakan desain grounded-theory. Penelitian dilaksanakan pada jenjang Sekolah Menengah Pertama (SMP) kelas 7 menggunakan dua desain pembelajaran yang berbeda. Kelas pertama menggunakan model pembejaran konvensional sedangkan pada kelas ke dua menggunakan model pembelajaran van Hiele berbantuan software Geometers' sketchpad. Hasil yang diperoleh dalam penelitian ini menunjukkan bahwa proses abstraksi teoretis mendominasi abstraksi siswa yang belajar pada kelas yang menggunakan model konvensional, sedangkan abstraksi siswa yang belajar konsep segitiga pada kelas yang menggunakan model van Hiele dengan bantuan Geometers' sketchpad didominasi oleh proses abstraksi empiris yang difasilitasi oleh software Geometers' sketchpad.
\end{abstract}

Kata Kunci: abstraksi matematis, segitiga, model van Hiele, Geometers'sketchpad

\begin{abstract}
Geometry has abstract notions to be learnt so that all those notions cannot be just transferred into students' mind like a bunch of information that should be memorized. Students need to construct those concepts during their learning process. This process of knowledge construction can be considered as an abstraction process. This study aimed to qualitatively compare abstraction process of students who learned the topic of triangle in conventional method and in van Hiele model of teaching aided by Geometers' sketchpad. Subjects of this study were junior high school students in grade 7 . This is a qualitative study with grounded theory design. Data were collected through classroom observation, test, and task-based interview. Results of the study show that theoretical abstraction processes tend to dominate classrom with conventional method of teaching while classroom with van Hiele model of teaching aided by Geometers' sketchpad accommodated empirical abstraction process of the students.
\end{abstract}

Keywords: mathematical abstraction, triangle, van Hiele model, Geometers'sketchpad

How to Cite: Nurhasanah, F., Kusumah, Y.S., \& Sabandar, J. (2017). Concept of triangle: Examples of mathematical abstraction in two different contexts. International Journal on Emerging Mathematics Education, 1(1), 53-70. D0I: http://dx.doi.org/10.12928/ijeme.v1i1.5782

\section{INTRODUCTION}

In learning mathematics, students interact with representations of mathematical objects and abstract mathematical ideas (Chazan \& Yerushalmy, 1998). Effective mathematics instruction calls for students' engagement with mathematical objects to 
construct knowledge. In school mathematics, particularly the learning of geometry requires appropriate instructional experiences that can assert students to sequentially move their thinking from concrete to abstract. Therefore the instructional experiences should be designed in order to facilitate process of abstraction in learning geometry.

Mitchelmore and White (2004) stated that there are still few researches and professional literature about abstraction topic in mathematics education field whereas this topic is very significant in creating effective mathematics education classroom, so that a comprehensive study is needed to create an effective mathematics instructional (Goodson \& Espy, 2005). Research about abstraction mostly discuss about how the abstraction takes place in learning process using certain context without comparing different contexts of learning and teaching such as did by Hazzan (2003), William (2007), and Hong \& Kim (2015). This study will focus on how the abstraction process takes place in two different contexts of teaching.

Creating a mathematics learning classroom is not simple; it should be rely on what learning process to be administered. Through a well design classroom interaction, students are guided to do abstraction process in learning mathematics with various strands such as algebra and geometry.

Laborde et al (2006) stated that there are many students around the world who have trouble in learning geometry. This condition also happened in Indonesia; there were many students in Indonesia having big problem in learning geometry (Nurhasanah, 2004; Nurhasanah, Sabandar, \& Kusumah, 2013). Studying the process of students' thinking when learning geometry concepts could be done for investigating students' difficulties of learning geometry.

Researches about geometry are mostly in line with van Hieles' theory for example study did by Olkun, Sinoplu, \& Deryakulu (2002). Pierre Marrie van Hiele and Dina van Hiele Geldof was spouse that had studied about how students learn geometry. They proposed two theories about learning and teaching geometry. First was a theory of thinking level for learning geometry and second was a theory of teaching with van Hiele's theory such as Saads \& Davis (1997); Choi-koh (2000); model to help students learn geometry. This model was designed in order to enhance students' ability in learning geometry by alleviating their geometry thinking level.

At the time when this theory was released, the tools for learning geometry were still limited. Nowadays, with the advance of information technologies, there are many tools which were transformed from real construction to digital form using computer. The tools are well known as interactive tools for learning geometry, one of the types is Dynamic Geometry Software (DGS). Some of the examples are, Geogebra, Wingeom, Geometers' Sketchpad, Cabri, Logo etc. These tools can help students in learning geometry.

Based on the study held by Choi-koh (2000) and Olkun et al (2002), Geometers' Sketchpad (GSP) could help teachers in creating classroom environment to build and develop thinking process especially in Geometry. This software was designed in order to help students learn Euclidian Geometry concepts. Embedding this software in van Hiele model of teaching geometry as a tool can help teachers as well as students to do: continuous real-time transformation or called as "dragging", move certain element of drawing freely, and observe other elements respond dynamically (Goldenberg \& Cuoco, 1998) which are also in line with the phases of teaching geometry in van Hiele model.

Triangle is one of fundamental concepts in Geometry, especially for junior high school students. In junior high school level, this basic concept for the first time learned

IJEME, Vol. 1, No. 1, March 2017, 53-70 
comprehensively by the students so that capturing students' thinking process while learning this concept is very interesting. This paper aims to analyze mathematical abstraction processes of students when learning concept of triangle in two different contexts. This study will provide information about how the abstraction process may take place in two different contexts. It can be used by mathematics teacher and researcher in the future for designing learning context and learning environment that lead to the mathematical abstraction.

\section{LITERATURE REVIEW}

\section{Abstraction, Generalization, and Representation}

Looking the word of "abstraction" in the Indonesian dictionary always leads to the word of "generalization" so that this term tends to be interpreted as generalization (Ferrari, 2003; Nurhasanah, 2010). These terms are often used interchangeability in literature. The fact is these two terms are not similar. Abstraction differs from generalization in term of its process; abstraction is a process related to the process of emerging a new concept or mental object while generalization is a process of extending the meaning of an existing concept (Mitchelmore \& White, 2000). Sometimes process of abstraction involves the extension of familiar processes in order to construct the concept. For example, when students learn a concept of triangle through many types of its representations, then they come up with the concept of triangle generalizing the properties of triangle into its definition. On the other hand in order to do generalisation someone needs to construct the concept first.

Representation is another concept involved in abstraction process. Both processes are complementing each other. Dreyfus (2002) stated that form of representation usually is the embodiment of more abstract concepts. However various representations of a concept could help students construct a new concept. On the other hand, students need to represent the concept learned into symbol or appropriate notion, of course this can only be happened after the abstraction processes take place. It can be inferred that abstraction, generalization, and representation are different terms which are interrelated one and another.

\section{Empirical and Theoretical Abstraction}

Abstraction is a cognitive process which is very complicated to define with simple sentence. It is related to the complexity of its process which is has been known by previous researchers such as Dreyfus (1991), Dreyfus \& Gray (2002), and Ferrari,(2003) There are several notions of abstraction defined by scholars. Aristotle probably the one who first proposed the idea of mathematical abstraction (Saitta, \& Zucker, 2013). Other scholars such as Piaget (1970), Skemp (1986), Dubinsky (2002) tried to formulate the notions of abstraction in learning mathematics.

According to Aristotle there were three types of abstraction, they were: Physical Abstraction, Mathematical Abstraction and Metaphysical abstraction. According to him, mathematical abstraction is happen when someone ignores the embodied object as and only keeps the intelligible ones; this activity is a kind of sensory characteristics. His notion of abstraction is much clearer when Skemp (1986) proposed the idea of mathematical abstraction using three terms, abstracting, and abstraction, he noted:

"Abstracting is an activity by which we become aware of similarities ... among our experiences. Classifying means collecting together our experiences on the basis of these similarities. An abstraction is some kind 
of lasting change, the result of abstracting, which enables us to recognise new experiences as having the similarities of an already formed class. ... To distinguish between abstracting as an activity and abstraction as its endproduct, we shall ... call the latter a concept."

It can be concluded that abstracting consists of activities and abstraction is the result of those activities. This concept of abstraction belongs to empirical abstraction, because this abstraction is based on experiences (Mitchelmore \& White, 2007).

Another notion of empirical abstraction was proposed by Piaget (1970). Piaget proposed three types of abstraction, empirical abstraction, pseudo-empirical abstraction, and reflective abstraction. Empirical abstraction is a process of focusing attention to the properties of objects in order to derive knowledge (Beth \& Piaget, 1966 in Dubinsky, 2002). This process leads to the extraction of commonalities of properties of objects and involves of doing something to the objects to get knowledge. Between the empirical abstraction and reflective abstraction there is a pseudoempirical abstraction, in this type of abstraction, the properties of subject in action were teased out from the object. The empirical and pseudo-empirical abstractions are constructing knowledge by doing some actions such as performing or imagining into the objects. In addition reflective abstraction involves the process of interiorizing and coordinating those actions in order to construct new actions that can lead to the forming of new knowledge. Dubinsky stated that based on Piaget's psychological point of view, new mathematical constructions proceed by reflective abstraction while Mitchelmore \& White, 2004 were prefer to use term of theoretical abstraction for this term.

They proposed two main theories in the abstraction processes: an empirical abstraction and theoretical abstraction. The concept of empirical abstraction was derived from Skemp's conception (1986) but the meaning of empirical abstraction by Skemp is much deeper than what Piaget proposed as an empirical abstraction (White \& Mitchelmore, 2010). Based on his conception, abstraction starts from similarity recognition then it is followed by embodiment of the similarity in a new mental object. On the contrary, in essence, theoretical abstraction consists of the creation of concepts to fit into some theory (Mitchelmore \& White, 2007). The difference between empirical abstraction and theoretical abstraction is that empirical abstraction constitute with the formation of mathematical objects as a model of experience otherwise theoretical abstraction deal with the development of mathematics as a consistent system.

However both abstraction processes are very significant in creating effective mathematics education classroom in order to achieve learning objectives of mathematics education (Goodson \& Espy, 2005). Related to the learning mathematics what can be inferred about this process? Dubinsky (2002) stated that:

"The main implication for education that our theory has, as far as we have taken it, is that, whatever happens, in or out of the classroom, the main concern should be with the students' construction of schemas for understanding concepts. Instruction should be dedicated to inducing students to make these constructions and helping them along in the process."

It means that teacher must facilitate this abstraction process in their mathematical classroom, not just transfer the mathematical objects into students' 
mind as a piece of information that must be memorized by students in order to recall it again later.

Based on the characteristics of fundamental mathematics ideas, study about how to teach for abstraction in the classroom resulted in some teaching model or teaching approach. Hershkowitz et al (2001) proposed an RBC + C model for teaching abstraction especially for non-empirical mathematical ideas such as complex number and geometrical construction that relied on the framework of theoretical abstraction. While White and Mitchelmore (2010) proposed a model called Teaching for Abstraction that can be applied for teaching mathematical concepts such as rate and ratio, change, fraction, angle, and other basic mathematical concepts that are multifaceted and closely link to everyday experiences that relied on the framework of empirical abstraction. Those models mentioned were design to promote abstraction in the learning process. However the abstraction process of students is not always easy to recognize. Indicators need to be addressed to analyze this process.

Based on the understanding both of theories of empirical abstraction and theoretical abstraction combined with the theory of generalization and representation, activities of abstraction in learning process can be identified from the following aspects:

1. Identifying the characteristics of the objects through direct experience

2. Identifying the characteristics of manipulated or imagined objects

3. Making generalization

4. Representing mathematical objects into symbols or mathematical language

5. Creating relationships between processes or concepts to form a new understanding

6. Applying the concepts into appropriate context

7. Manipulating abstract mathematical concepts

8. Removing material properties from an object or idealization

(Nurhasanah, Sabandar, \& Kusumah, 2013)

\section{Abstraction and van Hiele Model of Teaching}

According to Gray and Tall (2007) when students learn concepts of geometry such as angles, circle, triangle, quadrilateral etc, abstractions processes are needed in order to construct those concepts. Those empirical mathematical concepts are part of two dimensional geometry concepts for junior high school students. In addition, Mitchelmore and White (2007) stated that abstraction has significant role in learning geometry related to the formation of a triangle and quadrilateral concepts. For example, when students learn concept of a triangle or a quadrilateral, they start from identifying similarities by observing those shapes then doing classification based on the characteristics of the objects, finding the embodied properties of the concepts, and constructing a concept of each shape.

Theory of learning geometry proposed by van Hiele was developed based on theory of thinking levels in learning geometry (Crowley, 1987). There are five levels in thinking geometry: (1) level 1: recognition or visualization when students can visually recognize figures by their global appearance, (2) level 2: when students can start analyzing the properties of figures, learn the appropriate terminology for their description, recognize and name properties of geometric figures, but do not see relationships between these properties, (3) level 3: when students can logically order figures' properties by short chains of deductions and understand the interrelationships between figures, (4) level 4; when students can start developing 
longer sequences of statements and begin to understand the significance of deduction, the role of axioms, theorems and proof, and (5) level 5: when students can understand the formal aspects of deduction, such as establishing and comparing mathematical systems. In order to accomplish all those levels, students not only need to do empirical abstraction but also they need to do theoretical abstraction, especially for gaining level 4 and 5 .

Van Hiele also proposed the idea of teaching model for facilitating students to alleviate these levels of thinking. Based on van Hiele' model of teaching Geometry, there are five phases that need to be acomplished by students: (1) inquiry or information; (2) directed orientation; (3) Explication; (4) Free Orientation; and (5) Integration (Crowley, 1987). Inquiry or information phase is an initial stage when teacher provides activities for identify students' prior knowledge and introduce the geometric term that will be learned during the lesson. In the phase of directed orientation, teacher gives material which is designed gradually based on structure of the subjects. It can be stated that in this phase students are enriched by meaningfull learning activities. After having experiences in two previous phases, students come to the explication phase. In this phase teacher become facilitator to conduct classroom discussion when students are asked to express and exchange their emerging views about the structure that have been observed. One of the important role of teacher in this phase is guiding students in order to use the accurate and appropriate terms or language. The next phase is free orientation, in this phase students are given openended problems to be solved through investigation. Hopefully by solving those problems students can build some methemtical connection. The last phase is integration; students are given opportunity to build new level of thinking through summarizing what they have learned. Teacher plays a role as a facilitator in assisting the synthesis process. The new thinking domain will replace the old one in this phase, and then students are ready to repeat the learning phases in the next level.

Referring to the theory of abstraction and van Hiele's model of teaching geometry, the abstraction potential activities that probably emerge in learning phases of teaching can be seen on Table 1 .

Table 1. Relationships between van Hiele's Model of Teaching Geometry and Aspects of Abstraction

\begin{tabular}{|c|c|c|}
\hline $\begin{array}{c}\text { Steps of } \\
\text { Teaching } \\
\text { Geometry }\end{array}$ & $\begin{array}{l}\text { Abstraction Aspects that could be } \\
\text { Involved in every Phase }\end{array}$ & $\begin{array}{c}\text { Type of } \\
\text { Abstraction }\end{array}$ \\
\hline $\begin{array}{l}\text { 1. Inquiry/ } \\
\text { Information }\end{array}$ & $\begin{array}{l}\text { - Identifying the characteristics of the } \\
\text { objects through direct experience }\end{array}$ & $\begin{array}{l}\text { Empirical } \\
\text { abstraction }\end{array}$ \\
\hline $\begin{array}{l}\text { 2. Directed } \\
\text { Orientation }\end{array}$ & $\begin{array}{l}\text { - Identifying the characteristics of } \\
\text { manipulated or imagined objects }\end{array}$ & $\begin{array}{l}\text { Empirical } \\
\text { Abstraction }\end{array}$ \\
\hline 3. Explication & $\begin{array}{l}\text { - Representing mathematical objects } \\
\text { into symbols or mathematical } \\
\text { language } \\
\text { - Creating relationships between } \\
\text { processes or concepts to form a new } \\
\text { understanding }\end{array}$ & $\begin{array}{l}\text { Theoretical } \\
\text { Abstraction }\end{array}$ \\
\hline $\begin{array}{l}\text { 4. Free } \\
\text { Orientation }\end{array}$ & $\begin{array}{l}\text { - Idealization or removing material } \\
\text { properties from an object }\end{array}$ & $\begin{array}{l}\text { Theoretical } \\
\text { Abstraction }\end{array}$ \\
\hline
\end{tabular}


- Applying the concepts into appropriate context

- Making generalization

5. Integration

- Manipulating of abstract

Theoretical

mathematical concepts

Abstraction

- Creating relationships between

processes or concepts to form a new

understanding

During the development of van Hiele's model of teaching, technology for teaching geometry is not developed yet. Today, there exist a number of software for teaching geometry and widespread in many levels of education, such as Logo, Cabri, Geometers' Sketchpad, Geogebra, etc. Those softwares for teaching geometry are known as Dynamic Geometry Software (DGS). Some studies stated that, GSP as one of DGS can create potential situation in the classroom in order to build and develop thinking process in learning geometry that can lead to students' understanding on abstract concepts in geometry (Nurhasanah, Sabandar, \& Kusumah, 2013).

Using van Hiele model of teaching aided by GSP is far from traditional teaching method. Traditional method of teaching described as an ancient formal teaching method that involves directed flow information from teacher as a sage to students as receptacle (Raine \& Collett, 2003). Chapko \& Buchko (2004) defined traditional mathematics instruction as Method of instruction where the teacher presents a mathematical concept, reviews the procedures required to find the solution, and then has students practice these procedures with additional problems. In this study, traditional teaching context is consider as a classroom that use traditional mathematics teaching instruction.

\section{RESEARCH METHOD \\ Design of the Study}

Abstraction processes of Junior high school students in constructing concept of triangles were investigated in two different contexts. In the first context, teaching sequence was designed based on the van Hiele teaching phases aided by GSP and in the second context, teaching sequence was designed based on traditional teaching strategy that comprises: presenting mathematical concept; reviewing the procedures required to find solution for mathematical problems; and practicing the procedures for solving mathematical problems.. The topic of triangle was delivered in four-week teaching sequences. The topic comprised of the definition of triangle, area and perimeter of triangle, construction of triangle, angle bisector, altitude, and perpendicular bisector.

The study reported in this paper is guided by two research questions. The questions are:

1. What are the abstraction processes adopted by students in learning the concept of triangle using the traditional approach?

2. What are the abstraction processes adopted by students in learning the concept of triangle using the van Hiele model of teaching aided by the dynamic geometry software (GSP)? 
In order to answer those questions that are focused on investigating cognitive processes a qualitative approach with grounded method is the most suitable design for this study.

The participants of this studys were junior high school students in grade 7, aged between thirteen and fourteen years old from a public school in Indonesia. This study involved two classrooms 7A and 7B. Both classes consisted of 26 students unfortunately during the data collection processed only 25 students from $7 \mathrm{~A}$ participated on the study. Both classes consist of heterogenous students in term of mathematical achievment. Students in 7A were familiar with software GSP because the researcher conducted trainings using GSP for learning concept of lines, straight lines, perpendicular and parallel lines, and circles before the study take place.

Data for this study were collected through observation, test, and interview. The observation process conducted during learning process of triangle in the classroom. During this process all students' activities were observed and recorded. After students finished the learning process using two different models mentioned for about 4 weeks. Then the abstraction test was held to collect the information about what aspects of abstraction process which adopt by students in learning concept of triangle in two different contexts. The test consists of five questions which were designed based on abstraction indicator. Furthermore the interview process held after the test. The subjects of interview were 6 students from each of class. They were chosen based on the types of students' answers in solving the problems given. Result of interviews then transcribed and coded.

The process of obsevation and interview were recorded. A video-based interview was conducted for capturing the process of students' thinking in solving the problems. Students' answer sheets were used in the interview to confirm their writing and their thinking processes. In addition, observation notes were made based on the recorder result. The data from observation were gathered then summarized into observation notes. Data from test of abstraction were analyzed and then classified based on types of students' answers in every number. The result was used to determine subjects for interview process. All data from observation, test and interview were analyzed using analytic induction techniques and constant comparison (Alwasilah, 2003). The data were classified into some categories, and then verification measure between the categories is taken. Based on the defined categories, a posteriori act arose from data gathered, while maintaining the focus of study and theoretical framework.

\section{RESULTS AND DISCUSSION}

Guiding by the research questions, this session will present the finding of the study. This section addresses two research questions by reporting what has been found from the analysis:

What are the abstraction processes adopted by students in learning the concept of triangle using the traditional teaching approach?

Traditional teaching approach in this study means that the approach used to be implemented by mathematics teacher in the school where this study takes place. The teachers in this school used to use direct teaching for explaining topics in geometry. The lessons were mostly dominated by teacher's explaination and followed by giving examples. 
Based on the classroom observation notes aspects of identification of manipulated and imaginary objects, aspect of making generalization, and aspect of doing representation were not cleary captured in classroom but those aspects appeared in the testing and interviewing. In addition, based on data from videotape, interview and test the aspect of identifying the characteristics of the objects through direct experience is dominating the abstraction process of students in this classroom context. It can be seen from students' activities during the learning process such as, measuring the length of triangle sides using ruler and measuring size of interior angles of triangles using protractor, trying to rotate the figure of triangles from different point of view, and sketching triangles using compasses.

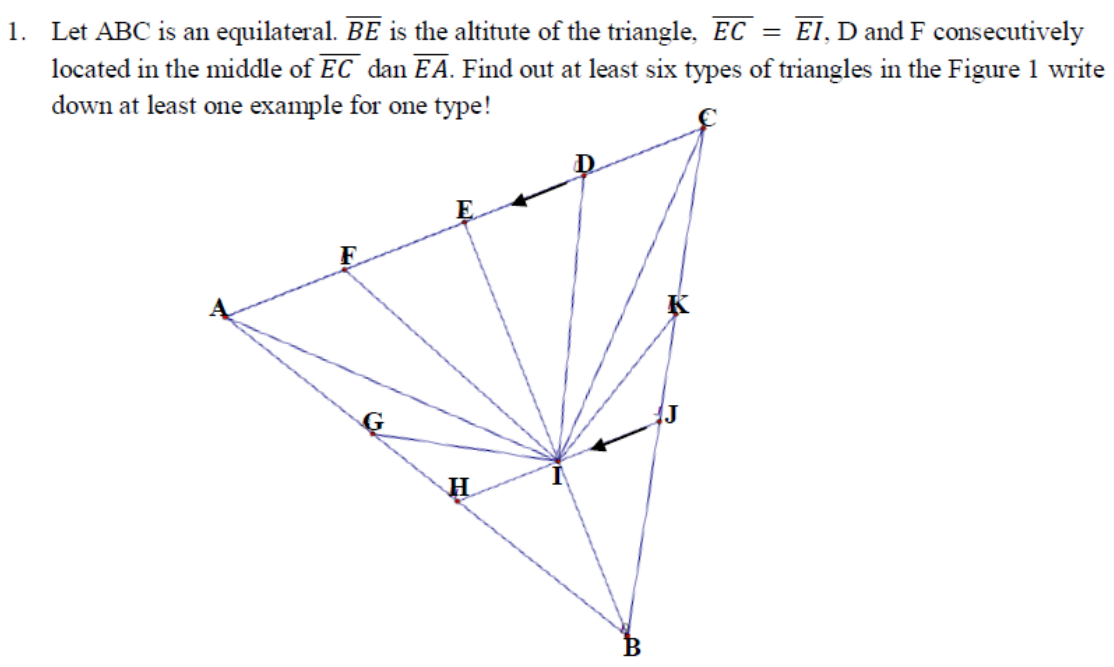

Figure 1. Problem Number 1

The aspect of identifying the characteristics of the objects through direct experience also dominantly appeared when students who learning in traditional teaching approach solving problems in the topic of triangle. In order to identify triangles in Figure 1, most students prefered to do direct measurement using ruler and protractor rather than used information given from problem statement. Consistently, it is also appered when students were trying to solve problem number 4, many of them were trying to solve the problem by cutting and folding the figure of triangle given on the picture. Below is transcript of interview with a student who learn in traditional learning context:

S : "for number $4, \ldots$. the first was I sketch the equilateral triangle using compass with the length of its side is $6 \mathrm{~cm}$, then I draw a line in every sides and fold the paper, so that I get a hexagon".

G : "So,... it means that you use a paper and craft it by your hand?"

S : "Yes,... I used a piece of paper then I cut the paper that has marked, then I folded it until I found a hexagon as a result. After that I sketched the hexagon in the answer sheet"

G : "the how did you find the length of its sides?"

$\mathrm{S}$ : "I measured it using ruler and I got $2 \mathrm{~cm}$ "

G : "Then why you did not measure the angles?"

S : "Hm,... I missed it .... I thought it was not asked"

G : "oh ok, if i ask you now how to get the measure of those angles, what would you do?" 
S : "Just measure it using protactor....."

"S" stands for "student" and "G" stands for "interviewer". This trancript was translated into English from Bahasa with some adjustment so that the contexts remain similar seen in Figure 2 .

4. Given an equilateral triangle $\mathrm{ABC}$ with the length of its sides is $6 \mathrm{~cm} . \mathrm{M}$ is intersection of all bisector of $\mathrm{ABC}$. If vertex $\mathrm{A}, \mathrm{B}$, and $\mathrm{C}$ are folded and coincide with $\mathrm{M}$, What geometry shape that you get? Find the length of its sides and the size of its angles!

Figure 2. Problem Number 4

The aspect of identification of manipulated and imaginary objects was not clearly appeared during classroom learning process but it can be recognized during the problem solving activities. There were 5 students identified who solved number 4 by using information from problem statement then processed it in mental action using their prior knowledge. In general the abstraction process adopted by student in learning concept of triangle using traditional approach as the context can be described in Figure 3.

According to Figure 3, aspect of generalization in this context is represented by a dash line, it is becauses this aspect only appeared in instructional process when teacher explain the concept of sum of interior angles in a triangle. Students were taking for granted the proof of this case. It's mean that only 6 from 8 aspects of abstraction that identified take place in this classroom context.

What are the abstraction processes adopted by students in learning the concept of triangle using the van Hiele model of teaching aided by the Geometers' Skecthpad (GSP)?

Van Hiele model of teaching aided by DGS was designed to promote mathematical abstraction of students in learning concepts of triangles. Lesson activities were designed based on van Hiele's model of teaching that consist of five phases.

Based on observation notes there are three abstraction aspects that dominantly appeared in this classroom, aspect of indentifying the characteristics of objects through direct experiences, identifying the characteristics of manipulated or imaginated objects, and representing mathematical objects into symbols or mathematical language. Most of abstractions aspects were easily recognized during the learning process in phase of directed orientation, it can be seen in Figure 6.

The role of DGS can be seen when students identified types of triangles in free orientation phase. Figure 4 is one of the example how DGS has helped a student identify triangles. She used different color for different types of triangles.

In solving problem number 1 , most students in this class were not doing direct measurement for identifying characteristic of triangle. Most of them used the information given on test and wrote it on their sheet, then conected the information with their prior knowledge in order to find the answer. The example of this case can be found in Figure 5.

One of the most prominant differences found is in the aspect of representing mathematical objects into symbols or mathematical language. Based on document of students' answer sheet there were no student in this class who used their own symbol for representing concepts such as triangle, angle, sides, etc, but this case was founded in class that learn using traditional context. In general, the aspects of abstraction that 
appeared in classroom that learn concept of triangle using van Hiele model of teaching aided by DGS are described in Figure 6.

\begin{tabular}{|c|c|c|}
\hline $\begin{array}{c}\text { Topic Related to } \\
\text { Triangle }\end{array}$ & Learning Steps & Aspects of Abstraction \\
\hline
\end{tabular}

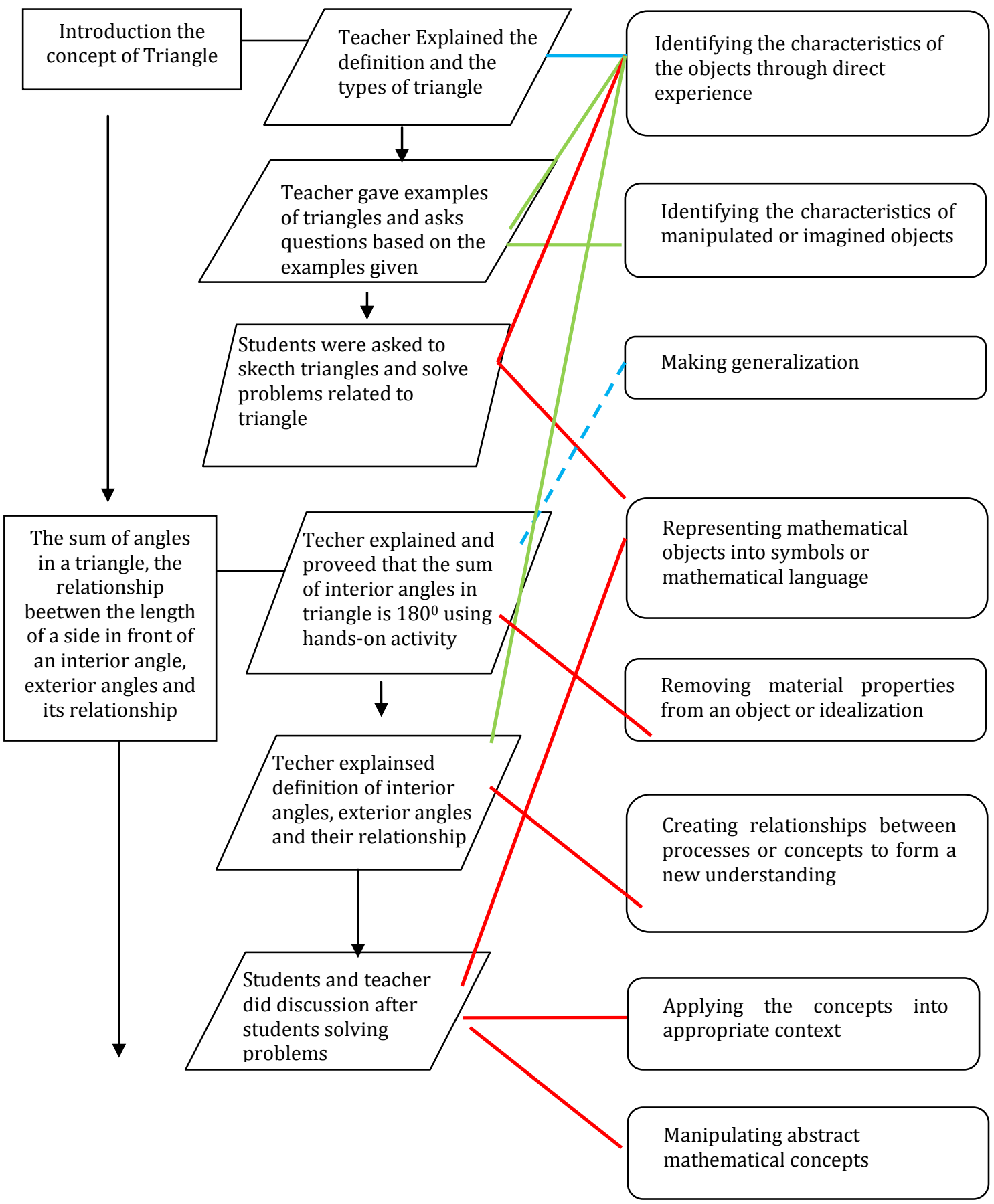




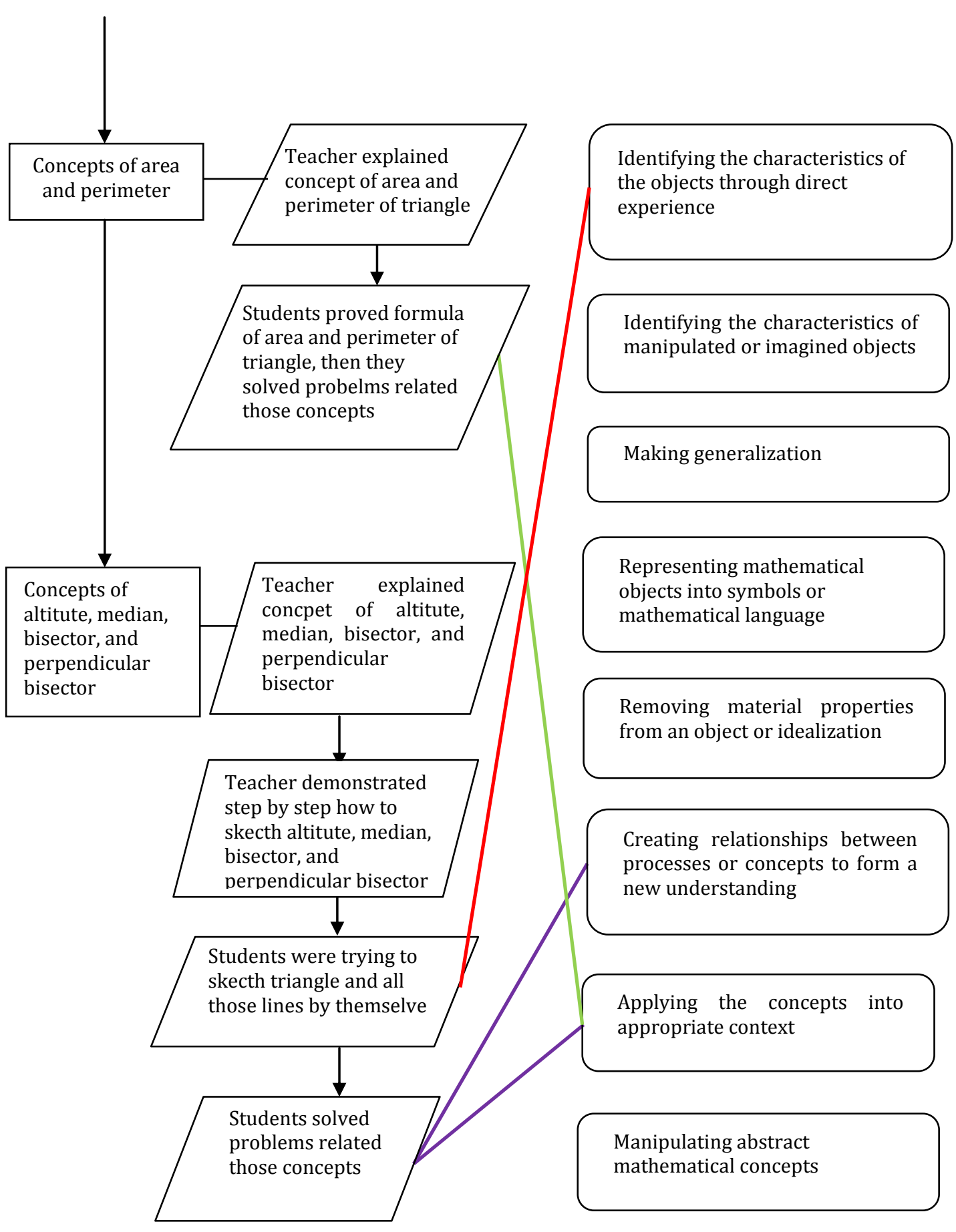

Figure 3. Abstraction Aspects in Learning Triangle in Traditional Learning Context

The process of construction mathematical concepts is complicated, it can take place individualy or collectively during classroom instructional process. The role of classroom context is significant for providing potential environment in triggering mathematical abstraction both individually and collectively. 


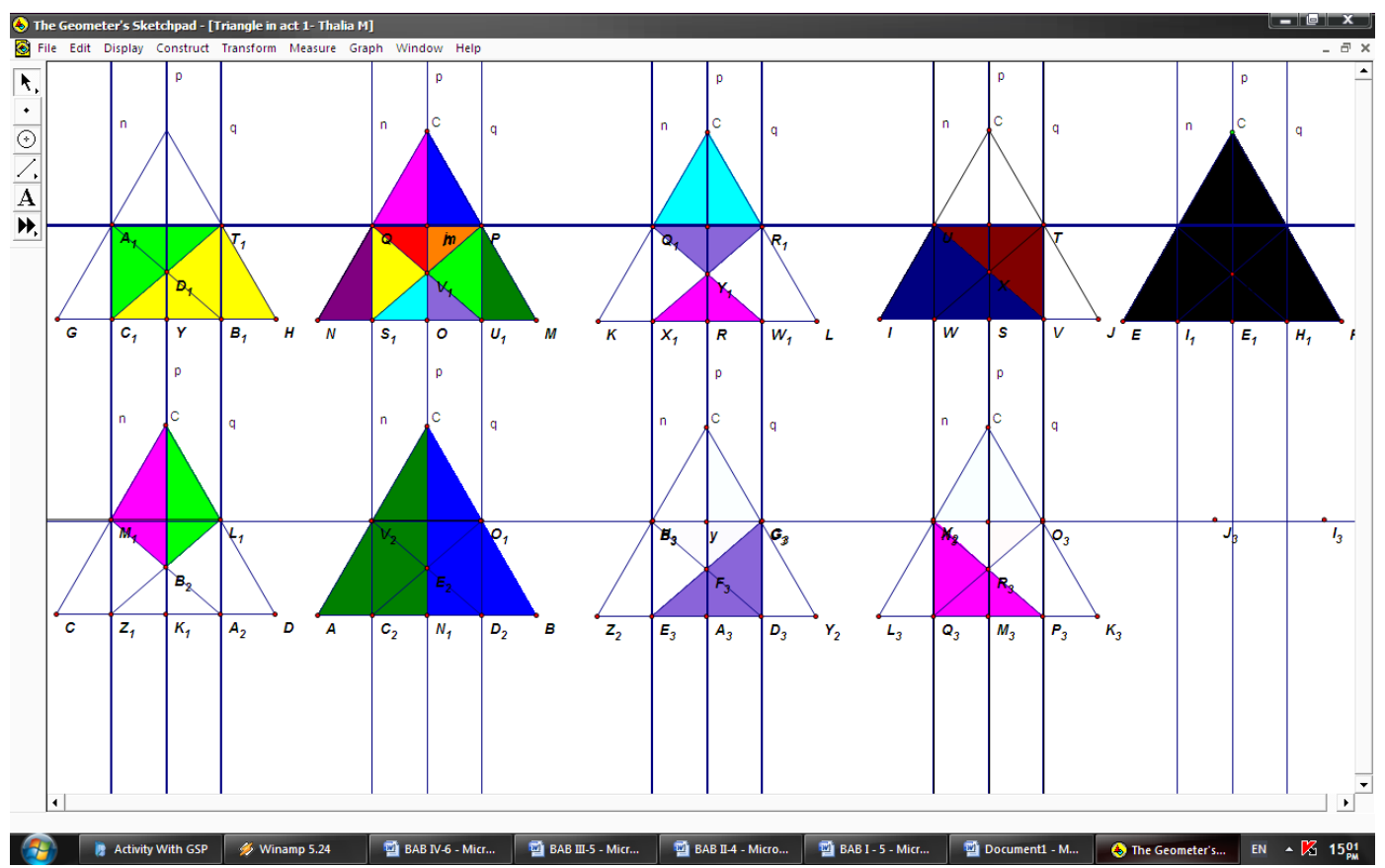

Figure 4. Example of How A Student Use DGS to Identify Types of Triangles

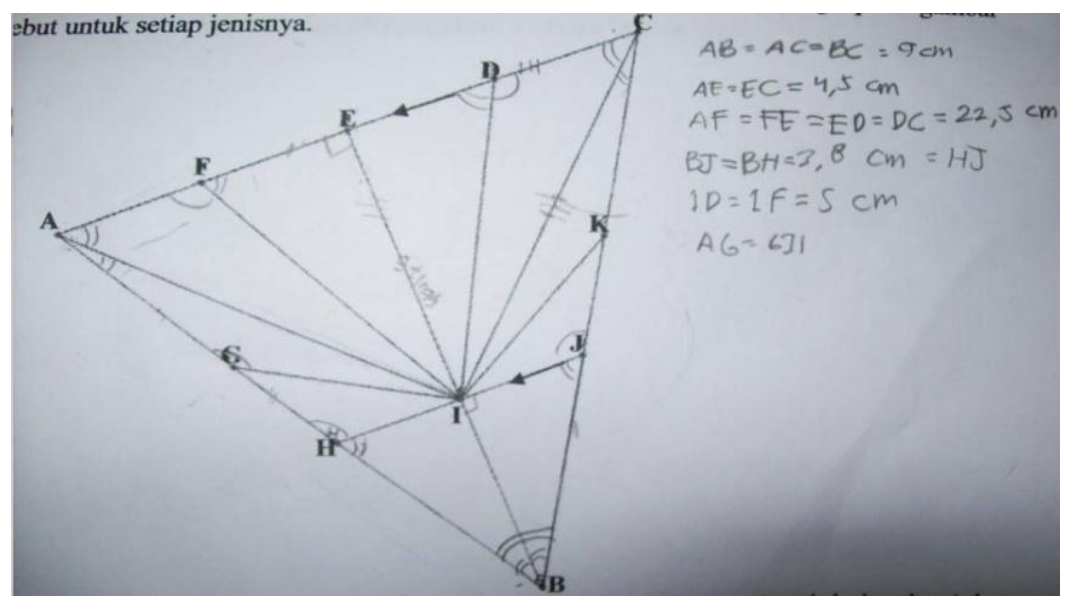

Figure 5. An Example of a Student's Identification Result for Problem Number 1

According to the result of this study, two different contexts of learning can lead different aspect of abstraction processes. Traditional context of classroom which is dominated by direct teaching method where re-construction of mathematical concepts were demonstrated by teacher is endorsing the position of mathematics as a kind of received knowledge. However it does not mean that abstraction process did not take place at all in this context. Based on the this study there are the most dominant aspect that identified take place in this context is aspect of identifying the characteristics of object through experiences during the instructional process as well as in process of solving problem in the topic of triangle. 
Topic Related to Triangle

\section{Van Hiele \\ Learning Phases}

Aspects of

Abstraction

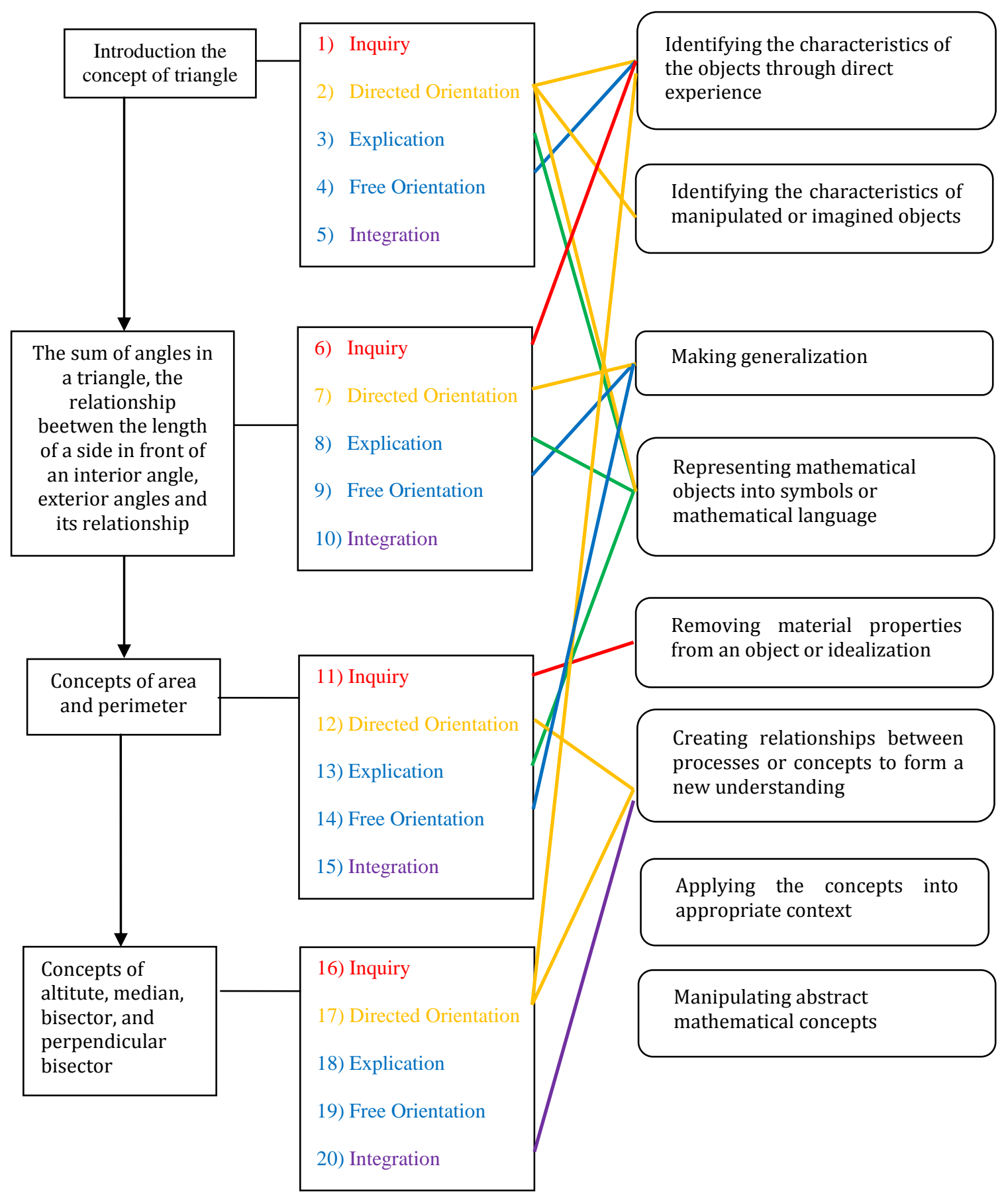

Figure 6. Abstraction Aspects in Learning Triangle in van Model of Teaching aided by DGS context

It is can be seen from activities such as measuring the length of the sides of triangle using ruler, measuring the angles of triangles using protractor, folding paper, 
rotating the image of the shape to saw a figure of shape from many point of view, and trying to draw a segment in a figure to help the student understanding the concept (Nurhasanah, 2011). This phenomenon can be explained as perception and be affected by experiences or current knowledge (Ross, 1996). Students used their experience in classroom to help them perceive the problem given.

Similar phenomena also found in classroom with van Hiele model of teaching aided by DGS, in this classroom, aspect of representing mathematical objects into symbols or mathematical language is dominantly appear among students when solving triangle problems. It can be explained that the role of DGS in introducing geometrical symbols and labeling process during the instructional process enriched students with knowledge and experiences with represention of geometrical symbols.

Differents contexts of learning lead different abstraction processes in learning geometry. As stated by Hoyles and Healy (1997) in lower levels, abstraction can be situated, the process take place within, and remain link to the context in which it first occur. Aspects of identificating the characteristics of object through experiences and representing mathematical objects into symbols or mathematical language are two aspects that sutable for level of perceptual abstraction and internalization as stated by Battista (2007).

\section{CONCLUSION}

This study showed that more aspects of abstraction in learning concept of triangle are accomodated through van Hiele model of teaching aided by DGS as classroom context comparing to traditional context. The van Hiele model of teaching aided by DGS context leads students to do empirical abstraction process both in learning process and in solving problems. However traditional teaching context leads students to do theoretical abstraction process in learning process and empirical abstraction in solving geometrical problems.

Based on the result of this study, investigation about level of thinking geometry and their abstraction process in different contexts can be an interesting further study. In addition, studies related to context for abstraction in higher levels of students also relevant as further study.

\section{REFERENCES}

Alwasilah, C. (2003). Pokoknya Kualitatif. Bandung: PT Kiblat Buku Utama.

Battista, M.T. (2007). The Development of Geometric and Spatial Thinking. In F. K. Lester (Ed.), Second Handbook of Research on Mathematics Teaching and Learning (pp. 843-908). Charlotte, NC: Information Age.

Chapko, M.A., \& Buchko, M. (2004). Math Instruction for Inquiring Minds: Two Principals Explain Why They Turned From Conventional Math Instruction to an Approach that Focuses on Understanding and Applying Math Concepts. Principal, 84(2), 30-33.

Chazan, D., \& Yerushalmy, M. (1998). Charting a course for secondary geometry. In R. Lehrer \& D. Chazan (Eds.), Designing learning environment for developing understanding of geometry and space (pp.67-90). Mahwah, Nj: Erlbaum.

Choi-Koh, S.S. (2000). The Activities Based on van Hiele Model Using Computer as a Tool. Journal of the Korea Society of Mathematics Education Series D: Research in Mathematics Education, 4(2), 63-67. 
Crowley, M.L. (1987). The Van Hiele Model of the Development of Geometric Thought. Learning and Teaching Geometry, K-12, 1-16.

Dreyfus, T., \& Gray, E. (2002). Research Forum "Abstraction: Theories about the emergence of knowledge structures". In Cockburn, A. and Nardi, E (Eds). Proceedings of the 26th Annual Conference of PME, Norwich: University of East Anglia, pp. 113-133.

Dreyfus, T. (1991). On the status of visual reasoning in mathematics and mathematics education. In Proc. 15th Conf. of the Int. Group for the Psychology of Mathematics Education (Vol. 1, pp. 33-48).

Dreyfus, T. (2002). The Nature of Advanced Mathematical Thinking. In David, T., (Ed). Advanced Mathematical Thinking (Vol. 11, pp. 25-41). New York: Kluwer Academic Publisher.

Dubinsky, E. (2002). Reflective Abstraction in Advanced Mathematical Thinking. In David, T. (Ed). Advanced Mathematical Thinking (Vol. 11, pp. 95-123). New York: Kluwer Academic Publishing.

Ferrari, P.L. (2003). Abstraction in mathematics. Philosophical Transactions of the Royal Society of London. Series B: Biological Sciences, 358(1435), 1225-1230.

Goldenberg, E.P., \& Cuoco, A.A. (1998). What is Dynamic Geometry? In R. Lehrer \& D. Chazan (Eds), Designing Learning Environments for Developing Understanding of Geometry and Space (pp. 351-368). Hillsdale, New Jersey: Lawrence Erlbaum Associates.

Goodson, T., \& Espy. (2005). Why Reflective Abstraction Remains Relevant In Mathematics Education Research. Proceedings of the 27th Annual Meeting of $P M E$, NA, Virginia Tech, October 20052.

Gray, E. \& Tall, D. (2001.) Relationships between embodied objects and symbolic procepts: an explanatory theory of success and failure in mathematics. In Heuvel-Panhuizen, M.(Ed.) Proceedings of the 25th conference of the international group for the psychology of mathematics education. Utrecht, Netherland: Freudenthal Institute.

Hazzan, 0. (2003). How students attempt to reduce abstraction in the learning of mathematics and in the learning of computer science. Computer Science Education, 13(2), 95-122.

Hershkowitz, R., Schwarz, B.B., \& Dreyfus, T. (2001). Abstraction in context: Epistemic actions. Journal for Research in Mathematics Education, 32, 195-222.

Hong, J.Y., \& Kim, M.K. (2015). Mathematical abstraction in the solving of ill-structured problems by elementary school students in Korea. Eurasia J. Math. Sci. \& Tech. Ed., 12(2), 267-281.

Hoyles, C., \& Healy, L. (1997). Unfolding Meanings for Reflective Symmetry. International Journal of Computers for Mathematical Learning, 2(1), 27-59.

Laborde, C., Chronis, K., Hollebrands, K., \& Stasser, R. (2006). Teaching and Learning Geometry with Technology. In Handbook of Research on the Psychology of Mathematics Education. Past, Present and Future. London: Sense Publisher. 
Mitchelmore, M.C., \& White, P. (2000). Development of Angle concepts by Progressive Abstraction and Generalization. Educational Studies in Mathematics, 41(3), 209238.

Mitchelmore, M \& White, P. (2004). Abstraction in Mathematics and Mathematics Learning. Proceeding of the $28^{\text {th }}$ Conference of the International Group for the Psychology of Mathematics Education, 3, 329-336.

Mitchelmore, M.C., \& White, P. (2007). Abstraction in Mathematics Learning. Mathematics Education Research Journal, 19(2), 1-9.

Nurhasanah, F. (2004). Proses Berpikir Siswa Sekolah Menengah Tingkat Pertama Dalam Belajar Geometri Pada Pokok Bahasan Jajargenjang, Belahketupat, Layang-Layang Dan Trapesium. Unpublished Thesis. FKIP UNS Surakarta.

Nurhasanah, F. (2010). Abstraksi Siswa SMP dalam Belajar Geometri Melalui Penerapan Model van Hiele dan Geometers' Sketchpad. Unpublished Thesis. Universitas Pendidikan Indonesia: Bandung.

Nurhasanah, F. (2011). Junior High School Students' Abstraction in Learning Geometry. Proceeding of International Seminar and the Fourth National Conference on Mathematics Education 2011, Department of Mathematics Education, Yogyakarta State University, Yogyakarta, July 21-23 2011.

Nurhasanah, F., Sabandar, J., \& Kusumah, Y.S. (2013). Abstraction Processes in Learning Geometry Using GSP. Proceeding of $6^{\text {th }}$ East Asia Regional Conference on Mathematics Education (Earcome6) 17-22 March 2013. Phuket: Prince Songkla University.

Olkun, S., Snoplu, N.B., \& Deryakulu, D. (2002). Geometric explorations with Dynamic Geometry Applications based on van Hiele Levels. International Journal for Mathematics teaching and Learning, 1(2), 1-12.

Piaget, J. (1970). Science of Education and Psychology of the Child. New York: Viking.

Raine, D., \& Colett, J. (2003). Problem-based learning in Astrophysics. European Journal of Physics, 24(2), 1-9.

Ross, B.H. (1996). Category representation and the effects of interacting with instances. Journal of Experimental Child Psychology: Learning, Memory, and Cognition, 22(5), 1249-1265.

Saads, S. \& Davis, G. (1997). Spatial abilities, van Hiele levels, and language use in three dimensional geometry. In Pehkonen, E. (Ed.), Proceedings of the 21st Conference of the International Group for the Psychology of Mathematics Education, 4, 104111. Lahti, Finland.

Saitta, L., \& Zucker, J.-D. (2013). Abstraction in Different Disciplines. In Saitta, L., \& Jean, -D., Z (Ed.), Abstraction in Artificial Intellegent and Complex System. New York: Springer.

Skemp, R. (1986). The Psychology of Learning Mathematics. London: Penguin.

White, P., \& Mitchelmore, M.C. (2010). Teaching for abstraction: A model. Mathematical Thinking and Learning, 12(3), 205-226.

William, G. (2007). Abstracting in the context of spontanious learning. Mathematics Education Research Journal, 19(2), 69-88. 
